\title{
Impact of Different Salinity Levels on Growing Performance, Food Conversion and Meat Quality of Red Tilapia (Oreochromis sp.) Reared in Seawater Tanks
}

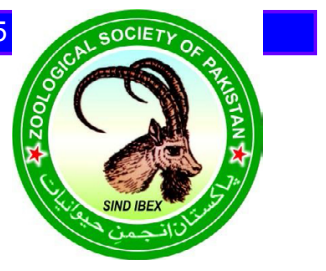

\author{
Abdul Malik ${ }^{1,2}$, Ghulam Abbas ${ }^{1, *}$, Abdul Ghaffar ${ }^{3}$, Sara Ferrando $^{4}$ and \\ Lorenzo Gallus ${ }^{4}$ \\ ${ }^{1}$ Centre of Excellence in Marine Biology, University of Karachi, Karachi, Pakistan \\ ${ }^{2}$ Livestock and Fisheries Department, Directorate of Fisheries, Govt. of Sindh, Pakistan \\ ${ }^{3}$ Department of Life Sciences, The Islamia University of Bahawalpur, Bahawalpur, \\ Pakistan \\ ${ }^{4}$ Department of Earth, Environment and Life Sciences, University of Genoa, Italy
}

A B S T R A C T

The effect of varying salinity levels ( $15 \%$ to $40 \%$ with $5 \%$ increment) on growth, feed efficie and meat quality of red tilapia, Oreochromis sp. (mean body weight $5 \pm 0.07 \mathrm{~g}$ ) were ip red tilapia were randomly distributed into seawater tanks $\left(60 \mathrm{~cm} \times 30 \mathrm{~cm} \times 45^{5}\right.$ stocked in each tank with 2 replications. Fish were fed with commercial floatil bellet (3. protein) at $3 \%$ body weight per day for 40 days. Results showed that fish growth was sign ntly (P .05) higher in term of weight gain, WG \% of initial weight, mean daily WG, SC survival rate from $15 \%$ to $30 \%$ salinity than those reared in $35 \%$ and $40 \%$ salin foctor was found to be significantly higher on $40 \%$ salinity than $15 \%$ to $35 \%$ salinity. Feed to remained non-significant in all salinity levels. Present study proves that a can $b$ ared up to 30\% salinity to get optimum growth and maximum survival rate. Bio nical lysis of h meat showed that moisture, protein, lipid, ash and crude fiber were not significan $P$ - Lffected by salinity level. The hematological parameters like hematocrit, cholest and pla triglyoundes were similar among fish fed on different salinity level $(P<0.05)$.

$\mathrm{S}_{\mathrm{ata}}^{\mathrm{at}}$ INT YP CTION

Simportap envin imenta actor which affects the growth perfor seawater ponds d cages (Cruz et al., 1990; Watanabe et al., 1990; Naylor al., 2000; Cressey, 2009; Ferreira et al., 2009; Martins et al., 2010; FAO, 2014; Cao et al., 2015). Salt control in these culture systems is a serious task for maintaining life in all higher organisms like bony fish including tilapia or cichlids. Cichlid have shown acceptance for rearing and spawning in brackish or seawater environment (Lim and Webster, 2008). Due to shortage of freshwater in the biosphere, it would be helpful to raise tilapia stocks in brackish or seawater environments to certify a source of low-priced and high-quality protein (animal origin) for future ( $\mathrm{Ng}$ and Romano, 2013; Saikia and Das, 2015). Therefore, tilapias may be suitable to reduce

\footnotetext{
* Corresponding author: ghulamabbas@uok.edu.pk 0030-9923/2018/0002-0409 \$ 9.00/0

Copyright 2018 Zoological Society of Pakistan
}

pressure on wild fish stocks (Dey, 2000; Ponzoni et al., 2011; Nguyen, 2015; Yue et al., 2016; Fitzsimmons, 2016). Cultivated tilapias attained marketable size from $600 \mathrm{~g}$ to $1000 \mathrm{~g}$ in 180-270 days of culture period, respectively. Due to these characters tilapias have been cultivated in 120 countries (Lim and Webster, 2008).

Red tilapia is gaining more popularity among fish culturist as its growth is excellent in brackish water and even in seawater (Stickney 1986; Daudpota et al., 2016). However, the data regarding salinity effect on its growth is scarce. The current research reports optimum salinity for desired growth, feed efficiency, adaptation and survival of red tilapia in captivity.

\section{MATERIALS AND METHODS}

Fingerlings of Red tilapia, Oreochromis sp. (mean body weight $5 \pm 0.07 \mathrm{~g}$ and mean total length $16.2 \pm 0.4 \mathrm{~cm}$ ) were collected from Sun-bright Red Tilapia and Ornamental Fish Hatchery. Subsequently, they were transported into Aquaculture Research Laboratory of Centre of Excellence 
in Marine Biology, University of Karachi. They were acclimated for one week and then stocked into seawater tanks $(60 \mathrm{~cm} \times 30 \mathrm{~cm} \times 45 \mathrm{~cm} ; 10$ fish per tank. $)$ at different salinity levels of $15 \%$, 20\%o, 25\%o, 30\%o, 35\%o and $40 \%$ with 2 replications. All tanks were well aerated throughout the experimental period. Artificial floating pelleted feed $(35 \%$ crude protein, $5.8 \%$ crude fat, $6.7 \%$ crude fiber, $9.8 \%$ moisture and $8.4 \%$ ash) was purchased from Oryza Organic Private Limited, Lahore. Fish were fed at 3\% of total biomass two time daily (9:00 and 16:00). Body weight and total length of individual fish was noted weekly and the amount of ration to be supplied to fish was then adjusted. Siphoning of each tank was done after $1 \mathrm{~h}$ feeding to remove waste material from bottom and new water was added to maintain required water level. Finally, growth performance and food conversion of fish juveniles were calculated by using the following formulae (Abbas and Siddiqui, 2013; Daudpota et al., 2016):

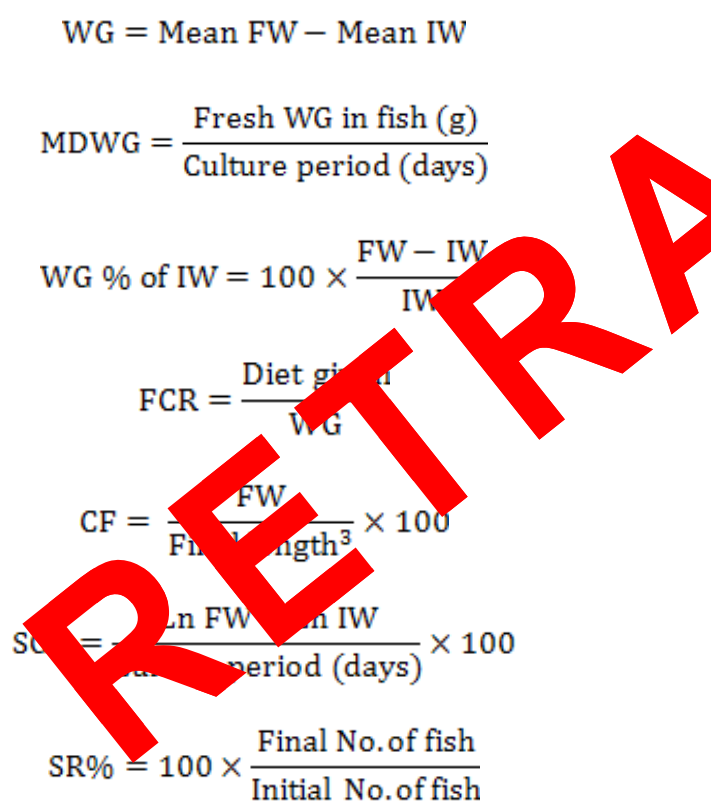

Where, WG is weight gain, FW is final weight, IW is initial weight, MDWG is mean daily weight gain, FCR is feed conversion ratio, $\mathrm{CF}$ is condition factor, $\mathrm{SGR}$ is specific growth rate and SR is survival rate.

Water quality parameters such as temperature, $\mathrm{pH}$, dissolved oxygen (DO) and ammonia were monitored throughout the study period. Temperature of the water was noted on daily basis by thermometer. DO of the water was noticed with the help of portable test kit (Merck KGaA, 64271, Germany). The $\mathrm{pH}$ of tank water was determined by using $\mathrm{pH}$ meter (EzDO 6011, Taiwan). Ammonia was determined with portable test kits (Merck KGaA, 64271, Germany) and salinity was observed by hand -held refractometer (ATAGO, S/Mill-E, 0.100\%, made in Japan) on daily basis.

At the end of the trial, fish meat was stored at $-20^{\circ} \mathrm{C}$ for biochemical analysis (AOAC, 2000). Blood samples $(1.50 \mathrm{ml})$ were taken from caudal vein of each fish by using anticoagulant (EDTA, $1 \mathrm{mg} / \mathrm{ml}$ ) and without it as well. The plasma constituents were determined by using the calorimetric methods of the Boehringer Corp as described by Papoutsoglou and Voutsinos (1988).

Data regarding weight and length increment, survival and biochemical constituents were statistically analyzed (Zar, 1996) by using statistical Minitab 17.

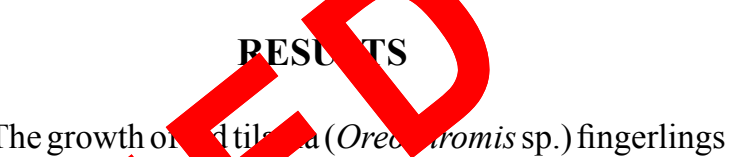
in term of $\mathrm{W}$ and $\mathrm{S}$ was nificantly $(\mathrm{P}<0.05)$ higher at $15 \%$ o than of those reared at $35 \%$ and 40\%o saln $\mathrm{v}$ (Table-1). Similar trend was found for $\mathrm{F}^{\prime} \mathrm{d}$ SR of fish. FCR was more or less similar $<0.05$ ) at all salinity levels (Table I). Condition factor ( $)$ of $t$ fish was found to be significantly $(\mathrm{P}<0.05)$ hig oo than those of $15 \%$ to $35 \%$. Relationship of mean fish weight was significantly $(\mathrm{P}<0.05)$ higher at oo to $30 \%$ o than $35 \%$ and $40 \%$ o salinity levels (Fig. 1). Water quality parameters like $\mathrm{pH}$, temperature, ammonia and dissolved oxygen were monitored daily throughout the experimental period. These parameters were within the acceptable range: water temperature was $28.32 \pm 0.09^{\circ} \mathrm{C}$, DO was $7.35 \pm 0.11 \mathrm{mg} / \mathrm{L}$, water $\mathrm{pH}$ was $7.8 \pm 0.11$ and ammonia never exceeded $0.023 \pm 0.005 \mathrm{mg} / \mathrm{L}$ (Table II). Relationship between body weight and total length of the present study shows that red tilapia fingerlings reared at $15 \%$, 20\%o, 25\%o and 30\%o was significantly $(\mathrm{P}<0.05)$ higher than $35 \%$ and $40 \%$ salinity levels (Fig. 2). Moisture, ash and protein contents of the cultured fish meat was not

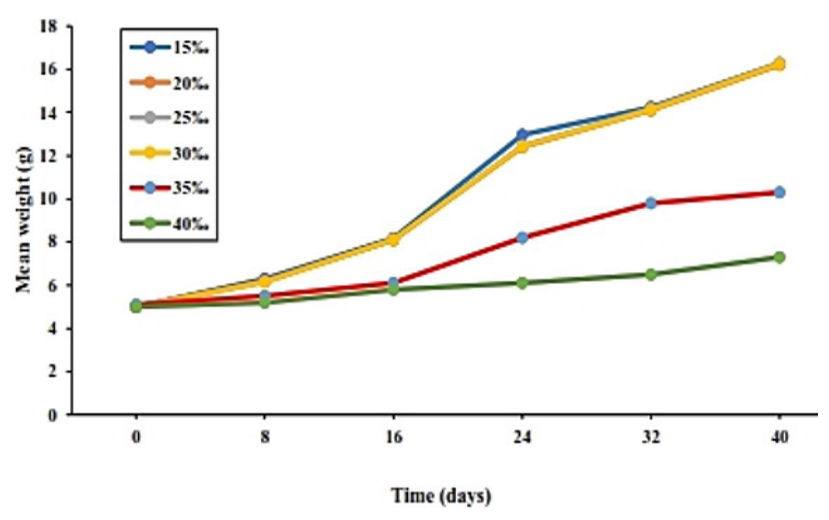

Fig. 1. Relationship between mean fish weight and time for fish reared at different salinity level. 
Table I.- Growth parameters of red tilapia (Oreochromis sp.) reared at different salinity level for 40 days.

\begin{tabular}{|c|c|c|c|c|c|c|}
\hline \multirow[t]{2}{*}{ Parameters } & \multicolumn{6}{|c|}{ Salinity level (\%o) } \\
\hline & 15 & 20 & 25 & 30 & 35 & 40 \\
\hline IW(g) & $5.0 \pm 0.07^{\mathrm{a}}$ & $5.0 \pm 0.05^{\mathrm{a}}$ & $5.0 \pm 0.04^{\mathrm{a}}$ & $5.0 \pm 0.07^{\mathrm{a}}$ & $5.1 \pm 0.6^{\mathrm{a}}$ & $5 \pm 0.05 \mathrm{a}$ \\
\hline $\mathrm{FW}(\mathrm{g})$ & $16.26 \pm 0.4^{\mathrm{a}}$ & $16.2 \pm 0.2^{\mathrm{a}}$ & $16.3 \pm 0.2^{\mathrm{a}}$ & $16.24 \pm 0.3^{\mathrm{a}}$ & $10.3 \pm 0.02^{\mathrm{b}}$ & $7.3 \pm 0.03^{b}$ \\
\hline IL (cm) & $6.44 \pm 0.05^{\mathrm{a}}$ & $6.48 \pm 0.08^{\mathrm{a}}$ & $6.48 \pm 0.08^{\mathrm{a}}$ & $6.48 \pm 0.07^{\mathrm{a}}$ & $6.4 \pm 0.02^{\mathrm{b}}$ & $6.4 \pm 0.01^{\mathrm{b}}$ \\
\hline $\mathrm{FL}(\mathrm{cm})$ & $11.74 \pm 0.2^{\mathrm{a}}$ & $11.68 \pm 0.14^{\mathrm{a}}$ & $11.66 \pm 0.15^{\mathrm{a}}$ & $11.74 \pm 0.13^{\mathrm{a}}$ & $9.4 \pm 0.01^{\mathrm{b}}$ & $6.9 \pm 0.02^{\mathrm{b}}$ \\
\hline WG & $11.26 \pm 0.01^{\mathrm{a}}$ & $11.3 \pm 0.07^{\mathrm{a}}$ & $11.3 \pm 0.01^{\mathrm{a}}$ & $11.24 \pm 0.03^{\mathrm{a}}$ & $5.2 \pm 0.03^{b}$ & $2.3 \pm 0.02^{\mathrm{b}}$ \\
\hline WG $\%$ of IW & $225.2 \pm 0.14^{\mathrm{a}}$ & $224 \pm 0.71^{\mathrm{a}}$ & $226 \pm 0.71^{\mathrm{a}}$ & $224.8 \pm 0.56^{\mathrm{a}}$ & $101.9 \pm 2.3^{\mathrm{b}}$ & $46 \pm 1.4^{\mathrm{b}}$ \\
\hline MDWG & $0.28 \pm 0.001^{\mathrm{a}}$ & $0.28 \pm 0.002^{\mathrm{a}}$ & $0.28 \pm 0.001^{\mathrm{a}}$ & $0.28 \pm 0.002^{\mathrm{a}}$ & & $0.06 \pm 0.002^{\mathrm{b}}$ \\
\hline SGR & $2.95 \pm 0.02^{\mathrm{a}}$ & $2.94 \pm 0.01^{\mathrm{a}}$ & $2.95 \pm 0.01^{\mathrm{a}}$ & $2.94 \pm 0.06^{\mathrm{a}}$ & & $0.95 \pm 0.02^{\mathrm{b}}$ \\
\hline FCR & $0.7 \pm 0.06^{\mathrm{a}}$ & $0.7 \pm 0.04^{\mathrm{a}}$ & $0.7 \pm 0.06^{\mathrm{a}}$ & $0.8 \pm 0.06^{\mathrm{b}}$ & & $0.7 \pm 0.04^{\mathrm{a}}$ \\
\hline FCE & $2.5 \pm 0.02^{\mathrm{a}}$ & $2.5 \pm 0.02^{\mathrm{a}}$ & $2.5 \pm 0.02^{\mathrm{a}}$ & & & $0.83 \pm 0.01^{\mathrm{b}}$ \\
\hline SR (\%) & $100 \pm 0.0^{\mathrm{a}}$ & $100 \pm 0.0^{\mathrm{a}}$ & $100 \pm 0.0^{\mathrm{a}}$ & & & $90 \pm 0.3^{b}$ \\
\hline $\mathrm{CF}$ & $1 \pm 0.01^{\mathrm{a}}$ & $1.02 \pm 0.02^{\mathrm{a}}$ & $1.03 \pm 0.01^{\mathrm{a}}$ & & & $2.2 \pm 0.02^{\mathrm{a}}$ \\
\hline
\end{tabular}

Values of the same row carrying the same superscripts are not statically significant $(\mathrm{P}>0.05)$. IW, tial weight, FW, final weight; IL, initial length; FL, final length; WG, weight gain; MDWG, mean daily weight gain; SGR, specific gro $;$ FCR, foo onversion ratio; FCE, food conversion efficiency; $\mathrm{SR}$, survival rate; $\mathrm{CF}$, condition factor.

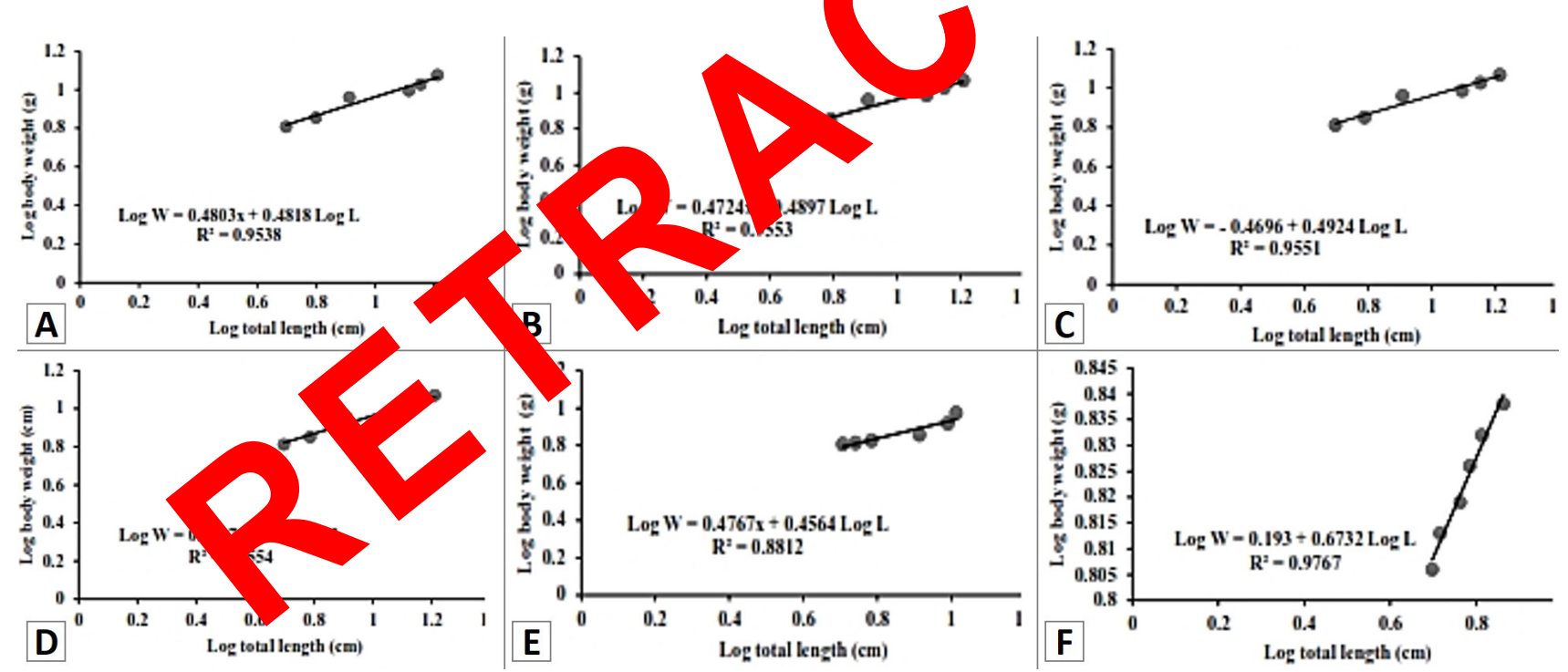

Fig. 2. Length-weight relationship of red tilapia fingerlings Oreochromis sp. reared on different salinity levels (A, 15\%; B, 20\%; C, $25 \%$; D, 30\%o; E, 35\% ; F, 40\%o).

affected $(P>0.05)$ by the salinity levels (Table III). No statistically important differences were observed between groups regarding the cholesterol level, plasma triglycerides and hematocrit values $(P>0.05$; Table IV, Fig. 3$)$.

\section{DISCUSSION}

In the present study, the salinity level of $30 \%$ was adequate to optimize $\mathrm{WG}, \mathrm{SGR}, \mathrm{CF}$ and survival rate in fingerling red tilapia growing from $5 \mathrm{~g}$ to $16.3 \mathrm{~g}$. SGR of the fish was higher at $15 \%$, 20\%o, 25\%o and 30\%o than reported by other researchers. For instance, Rahim et al. (2017) found $\mathrm{SGR}=3.21 \%$ while using fish oil, soybean oil, olive oil and palm oil in the diet of black fin sea bream (Acanthopagrus berda). These observations are higher than those of the present study (SGR: 2.82\%-2.83\%). Furthermore, Kapute et al. (2016) achieved maximum results i.e., 1.8 for Tilapia rendalli in pond $\left(200 \mathrm{~m}^{2}\right)$. In addition, Abbas and Siddiqui (2009) reported SGR $0.9 \%$ to $2.2 \%$ at different feeding levels of mangrove 
red snapper (Lutjanus argentimaculatus). Solomon and Okomoda (2012) found that SGR of Oreochromis niloticus ranged from $0.65 \%$ to $1.4 \%$ as different duckweed percentages were used in artificial feed. Daudpota et al. (2016) documented SGR of $2.1 \%-2.2 \%$ in comparative study of tilapia Oreochromis species. In another study of Daudpota et al. (2014), red tilapia showed SGR values ranging from $1.46 \%-1.69 \%$ on different stocking densities.

Table II.- Water quality parameters recorded at different salinity levels with mean values and standard error throughout the study period of $\mathbf{4 0}$ days.

\begin{tabular}{lcccc}
\hline $\begin{array}{l}\text { Salinity } \\
(\mathbf{\%})\end{array}$ & $\begin{array}{c}\text { Temperature } \\
\left({ }^{\circ} \mathbf{C}\right)\end{array}$ & $\begin{array}{c}\text { DO } \\
(\mathbf{m g} / \mathbf{L})\end{array}$ & $\mathbf{p}^{\mathbf{H}}$ & $\begin{array}{c}\text { Ammonia } \\
(\mathbf{m g} / \mathbf{L})\end{array}$ \\
\hline 15 & 28.3 & 7.4 & 7.8 & 0.02 \\
20 & 28.2 & 7.5 & 7.9 & 0.02 \\
25 & 28.4 & 7.4 & 7.6 & 0.02 \\
30 & 28.4 & 7.3 & 7.8 & 0.02 \\
35 & 28.2 & 7.2 & 7.9 & 0.03 \\
40 & 28.4 & 7.3 & 7.8 & 0.03 \\
Mean & 28.32 & 7.35 & 7.8 & 0.023 \\
SE \pm & 0.09 & 0.11 & 0.11 & 0.005 \\
\hline
\end{tabular}

In the present study, WG of the fish was wher th documented by various researchers. Okomoda (2012) reported gain in yeig fr $156 \mathrm{~g}$ to $1.92 \mathrm{~g}$ of Oreochromis niloticy when d weea vas included in its diet with differer a entration audpota et al. (2016) found WG fro $2.5 \mathrm{~g}$ to $\mathrm{g}$ of Nile tilapia. FCR of the fish was 07 at all salin levels. Similar results have been repon other fish, such as black fin sea bream Acan grus rda him et al. (2017a,b,c), red tilapia $O$ ochr his sp. audpota et al., 2014 and 2016), Nile is iloticus (Solomon and Okomoda, 2012).

In artificial o farming system, water quality parameters are directly affected by fish metabolism and feeding efficiency as well (Ertan et al., 2015; Kapute et al., 2016). In this study, water quality parameters were within the acceptable range for fish farming (Daudpota et al., 2014; Malik et al., 2014; Iqbal et al., 2014; Emmanuel et al., 2014; Shah et al., 2014 and Chugtai et al.,2015).

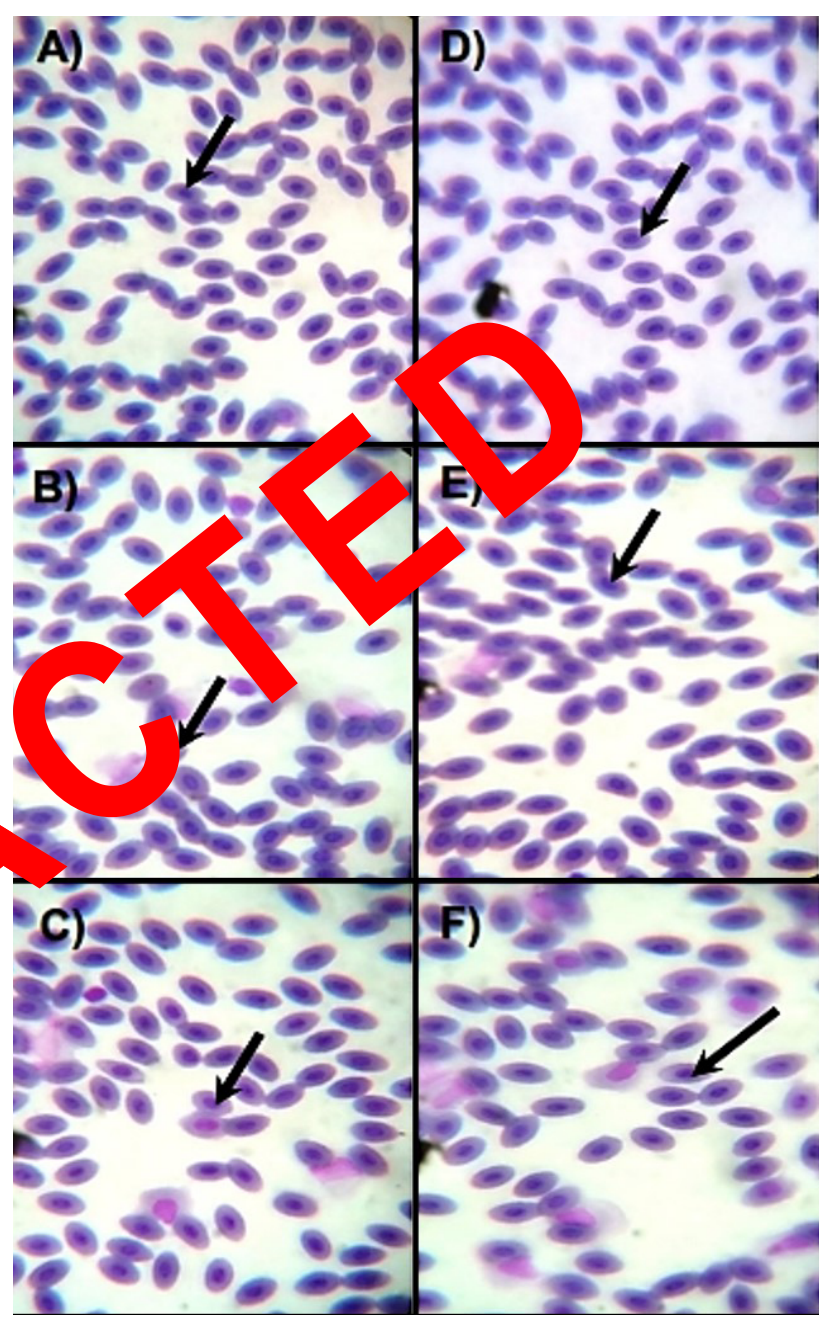

Fig. 3. Blood smear of red tilapia fingerlings Oreochromis sp. reared on different salinity levels (A, 15\%; B, 20\%; C, 25\%; D, 30\%; E, 35\%; F, 40\%o). Arrow, micronucleus (Giemsa stained: 1000X).

Table III.- Biochemical composition of Red tilapia hybrid (Oreochromis sp.) reared in glass tanks for the period of 40 days.

\begin{tabular}{lccccccc}
\hline & \multicolumn{7}{c}{ Salinity level (\%o) } \\
\cline { 2 - 7 } & Initial & $\mathbf{1 5}$ & $\mathbf{2 0}$ & $\mathbf{2 5}$ & $\mathbf{3 0}$ & $\mathbf{3 5}$ & $\mathbf{4 0}$ \\
\hline Crude protein (\%) & $16.21 \pm 0.1^{\mathrm{a}}$ & $17.16 \pm 0.2^{\mathrm{a}}$ & $17.23 \pm 0.3^{\mathrm{a}}$ & $17.18 \pm 0.4^{\mathrm{a}}$ & $17.26 \pm 0.3^{\mathrm{a}}$ & $17.23 \pm 0.2^{\mathrm{a}}$ & $17.21 \pm 0.2^{\mathrm{a}}$ \\
Moisture (\%) & $70.57 \pm 0.1^{\mathrm{a}}$ & $71.16 \pm 0.2^{\mathrm{a}}$ & $71.23 \pm 0.3^{\mathrm{a}}$ & $71.18 \pm 0.4^{\mathrm{a}}$ & $71.26 \pm 0.3^{\mathrm{a}}$ & $71.23 \pm 0.2^{\mathrm{a}}$ & $71.21 \pm 0.2^{\mathrm{a}}$ \\
Lipid (\%) & $2.49 \pm 0.3^{\mathrm{a}}$ & $2.52 \pm 0.2^{\mathrm{a}}$ & $2.50 \pm 0.1^{\mathrm{a}}$ & $2.51 \pm 0.2^{\mathrm{a}}$ & $2.49 \pm 0.2^{\mathrm{a}}$ & $2.50 \pm 0.1^{\mathrm{a}}$ & $2.48 \pm 0.1^{\mathrm{a}}$ \\
Ash (\%) & $4.13 \pm 0.4^{\mathrm{a}}$ & $4.18 \pm 0.3^{\mathrm{a}}$ & $4.18 \pm 0.4^{\mathrm{a}}$ & $4.17 \pm 0.4^{\mathrm{a}}$ & $4.17 \pm 0.4^{\mathrm{a}}$ & $4.16 \pm 0.4^{\mathrm{a}}$ & $4.16 \pm 0.1^{\mathrm{a}}$ \\
Crude fiber (\%) & $2.04 \pm 0.1^{\mathrm{a}}$ & $2.04 \pm 0.1^{\mathrm{a}}$ & $2.65 \pm 0.1^{\mathrm{a}}$ & $2.63 \pm 0.1^{\mathrm{a}}$ & $2.66 \pm 0.1^{\mathrm{a}}$ & $2.58 \pm 0.3^{\mathrm{a}}$ & $2.57 \pm 0.1^{\mathrm{a}}$ \\
\hline
\end{tabular}


Table IV.- Hematological parameters of juvenile red tilapia fed at different salinity levels for $\mathbf{4 0}$ days.

\begin{tabular}{lcccccc}
\hline Parameters & \multicolumn{6}{c}{ Salinity level (\%o) } \\
\cline { 2 - 7 } & $\mathbf{1 5}$ & $\mathbf{2 0}$ & $\mathbf{2 5}$ & $\mathbf{3 0}$ & $\mathbf{3 5}$ & $\mathbf{4 0}$ \\
\hline Haematocrit $^{1}$ & $42.2 \pm 3.1^{\mathrm{a}}$ & $42.3 \pm 6.2^{\mathrm{a}}$ & $43.3 \pm 4.3^{\mathrm{a}}$ & $43.1 \pm 3.1^{\mathrm{a}}$ & $43.2 \pm 6.2^{\mathrm{a}}$ & $43.4 \pm 5.2^{\mathrm{a}}$ \\
Total lipids $^{2}$ & $1385.3 \pm 67.1^{\mathrm{a}}$ & $1369.8 \pm 58.2^{\mathrm{a}}$ & $1322.4 \pm 56.6^{\mathrm{a}}$ & $1353.6 \pm 60.6^{\mathrm{ab}}$ & $1383.5 \pm 52.2^{\mathrm{a}}$ & $1371.2 \pm 49.9^{\mathrm{a}}$ \\
Triglycerides $^{2}$ & $163.4 \pm 55.0^{\mathrm{a}}$ & $166.2 \pm 56.1^{\mathrm{a}}$ & $169.4 \pm 55.6^{\mathrm{a}}$ & $167.8 \pm 52.1^{\mathrm{a}}$ & $165.5 \pm 58.2^{\mathrm{a}}$ & $169.1 \pm 56.0^{\mathrm{a}}$ \\
Cholesterol $^{2}$ & $151.0 \pm 40.3^{\mathrm{a}}$ & $155.1 \pm 48.2^{\mathrm{a}}$ & $156.9 \pm 46.2^{\mathrm{a}}$ & $154.8 \pm 50.4^{\mathrm{a}}$ & $153.7 \pm 51.5^{\mathrm{a}}$ & $154.1 \pm 52.0^{\mathrm{a}}$ \\
\hline
\end{tabular}

${ }^{1}$ Measured as \%; ${ }^{2}$ Measured as $\mathrm{mg} 100 \mathrm{ml}^{-1}$; Values (mean $\pm \mathrm{SE}, n=3$ ) in the same row with similar superscripts are not significantly different $(P>0.05)$; Initial fish blood analysis: hematocrit $42.6 \%$, total plasma lipids $1485.2 \mathrm{mg} 100 \mathrm{ml}^{-1}$, triglycerides $166.9 \mathrm{mg} 100 \mathrm{ml}^{-1}$ and cholesterol $149.9 \mathrm{mg}^{100 ~ m l^{-1}}$.

Generally, blood is considered as a tool for the transportation of nutrients, metabolites and inorganic ions (Abbas and Siddiqui, 2009). In the present study, all fishes were found to be healthy over the duration of the experiment and the values of the haematocrit were in normal range. Evidence to support this is available in another study of Papotsoglou and Voutsinos (1988). Similar individual tendency has been reported in rainbow trout Salmo gairdneri (Papoutsoglou and PapaparaskevaPapoutsoglou, 1979; Hile 1982; Papoutsoglou and Voutsinos, 1988), mangrove red snapper Lutjanus argentimaculatus (Abbas and Siddiqui, 2013) and rex spotted grouper Epinephelus akaara (Kayano et al., 19 Kang'ombe and Brown, 2008). In most of the abov studies, great differences in plasma lipids and cholestero levels were observed among groups for chemically different foods. In this study, salinity level did not cause any significant differentiation in the amount of these hematological parameters.

In conclusion, the growth performance, adaptation and survival of red tilapia was higher up to salinity level of 30\% than 35\% and $40 \%$ On the basis of these results, this specie can be recommended for coastal aquaculture or inland saline water areas to promote the brackish/ saline water aquaculture of Pakistan.

\section{CONCLUSION}

It is concluded that red tilapia fingerlings can be reared up to $30 \%$ salinity level it would be more productive for saline areas as well as coastal fish culturist.

\section{ACKNOWLEDGMENTS}

The authors gratefully acknowledge the research grant (No. AS 020/2017-19) entitled "Fish Breeding and Culture Technology Development in Coastal Region of Pakistan" provided by ALP-PARC, Islamabad. The senior author would like to pay gratitude to HEC for providing fellowship to complete this work as a part of his Ph.D. The authors are extremely thankful to Prof. Dr. Raida Wajih
Khalil, Faculty of Science, Department of Biotechnology, University of Philadelphia, who red and corrected this manuscript. Special thanks are due to Science Edit- DW for providing edit services.

Statement of conflict of interest Authors have declared no conflict of interest.

\section{REFERENCES}

Abbas, G. and Siddiqui, P.J.A., 2009. Effects of different hing level on the growth, feed efficiency and body composition of juvenile mangrove red snapper, Lutjanus argentimaculatus (Forsskal 1775). Aquacul. Res., 40: 781-789. https://doi. org/10.1111/j.1365-2109.2008.02161.x

Abbas, G. and Siddiqui, P.J.A., 2013. The effects of varying dietary protein level on growth, feed conversion, body composition and apparent digestibility coefficient of juvenile mangrove red snapper, Lutjanus argentimaculatus (Forsskal 1775). Aquacul. Res., 44: 807-818. https://doi. org/10.1111/j.1365-2109.2012.03096.x

AOAC., 2000. Official methods of analysis of association of official analytical chemists. 17th edn. Association of Official Analytical Chemists, Arlington, USA.

Cao, L., Naylor, R., Henriksson, P., Leadbitter, D. and Metian, M., 2015. China's aquaculture and the world's wild fisheries. Science, 347: 133-135. https://doi.org/10.1126/science.1260149

Chughtai, M.I., Mahmood, K. and Awan, A.R., 2015. Growth performance of carp species fed on salttolerant roughages and formulated feed in brackish water under polyculture system, Pakistan J. Zool., 47: 775-781.

Cressey, D., 2009. Aquaculture: future fish. Nature, 458: $398-400$. https://doi.org/10.1038/458398a

Cruz, E.M., Rhidha, M. and Abdullah, M.S., 1990. Production of African freshwater tilapia $O$. spilurus (Gunther) in seawater. Aquaculture, 84: 41-48. 
https://doi.org/10.1016/0044-8486(90)90298-2

Daudpota, A.M., Abbas, G., Kalhoro, I.B., Shah, S.S.A., Kalhoro, H., Rehman M.H. and Gaffar, A., 2016. Effect of feeding frequency on growth performance, feed utilization and body composition of Nile tilapia, Oreochromis niloticus, cultured in low salinity water. Pakistan J. Zool. 48: 171-177.

Daudpota, A.M., Siddiqui, P.J.A., Abbas, G., Narejo, N.T., Shah, S.S.A., Khan, N. and Dastagir, G., 2014. Effect of dietary protein level on growth performance, protein utilization and body composition of Nile tilapia cultured in low salinity water. Int. J. Int. Mult. Stud., 2: 135-147.

Dey, M.M., 2000. The impact of genetically improved farmed Nile tilapia in Asia. Aquacul. Econ. Manage., 4: 107-124. https://doi. org/10.1080/13657300009380263

Emmanuel, T.D.M., Felix, K.Y.A. and Ken, A., 2014. Comparative growth study of Oreochromis niloticus and Sarotherodon galilaeus under two different culture regimes (Hapa-In-Pond and cage systems). Int. J. Fish. aquat. Stud., 1: 53-59.

Ertan, E., Agrah, N. and Tarkan, A.S., 2015. The effect of salinity, temperature and feed ratio on growth performance of European sea bass labrax L., 1758) in the water o reverse osmosis system and a natura J. Zool., 47: 625-633.

FAO, 2014. The state of world fisheries and aquaculture. Rome, pp. 223.

Ferreira, J.G., Sequeira, A.,Hawkins, A.J.S., Newton, A. and Nickell, T.D., 2009. Analysis of coastal and offshore aquaculture. Application of the FARM model to multiple systems and shellfish species. Aquaculture, 289. 32-41. https://doi.org/10.1016/j. aquaculture 2008.12.017

Abbas, G. and Siddiqui, P.J.A., 2009. Effect of Different feeding levels on the growth, feed efficiency abd boday composition of juvenile mangrove red snapper, Lutjanus argentimaculatus (Forsskal 1775). Aquacul. Res., 40: 781-789. https://doi. org/10.1111/j.1365-2109.2008.02161.x

Hile, S., 1982. A literature review of the blood chemistry of rainbow trout, Salmo gairdneri, rich. J. Fish Biol., 20: 535-569. https://doi. org/10.1111/j.1095-8649.1982.tb03954.x

Iqbal, R., Ali, M., Narejo, N.T. and Umar, K., 2014. Effect of varying levels of protein from different animal sources on growth and survival of carp, Cirrhinus mrigala, reared in cemented cisterns. Pakistan J. Zool., 46: 1599-1604.

Kang'ombe, J. and Brown, J.A., 2008. Effect of salinity on growth, feed utilization, and survival of Tilapia rendalli, under laboratory conditions. J. appl. Aquacul., 20: 256-271.

Kapute, F., Valeta, J., Likongwe, J., Kang'ombe, J., Nagoli, J. and Mbamba, D., 2016. Growth performance of three tilapia fish species raised at varied pond sizes and water depths. Int. J. Fish. Aquacul., 8: 81-86. https://doi.org/10.5897/ IJFA2016.0566

Kayano, Y., Yao, S., Yamamoto, S. and Nakagawa, H., 1993. Effects of feeding frequency on the growth and body constituents of young red-spotted grouper, Epinephelus akaara. Aquaculture, 110: 271-278. https://doi.org/10.1016/0044-8486(93)90375-9

Lim, C. and Webster, C.D., 2008. Tilapia: biology, culture and nutrition. Afri. aquat. Sci., 33: 103-103.

Malik, A. Waryani, B., Kalhor, I.B., Kalhoro, H., Shah, S.A. and Narejo, N.T, 2014. To observe the effect of growth performance and adaptation of exotic fish red tilapia (hybrid) in climate of Fish Hatchery Chilya, Thatta, Sindh-Pakistan. Sindh Univ. Res. J. (Sci. Ser.), 46: 461- 464.

C.I.M., Eding, E.H., Verdegem, M.C.J., Heinsbroek, L.T.N. and Schneider, O., 2010. New developments in recirculating aquaculture systems in Europe: A perspective on environmental sustainability. Aquacul. Engin., 43: 83-93. https:// doi.org/10.1016/j.aquaeng.2010.09.002

Naylor, R.L., Goldburg, R.J., Primavera, J.H., Kautsky, N. and Beveridge, M.C.M., 2000. Effect of aquaculture on world fish supplies. Nature, 405: 1017-1024. https://doi.org/10.1038/35016500

Ng, W.K. and Romano, N., 2013. A review of the nutrition and feeding management of farmed tilapia throughout the culture cycle. Rev. Aquacul., 5: 220254. https://doi.org/10.1111/raq.12014

Nguyen, N.H., 2015. Genetic improvement for important farmed aquaculture species with a reference to carp, tilapia and prawns in Asia: achievements, lessons and challenges. Fish Fisher., 17: 483-506. https:// doi.org/10.1111/faf.12122

OECD/FAO, 2015. Agricultural outlook 2015. OECD Publishing, Paris, pp. 143.

Papoutsoglou, S.E. and Papaparaskeva-Papoutsoglou, E., 1979. Further observations on haematological and liver characteristics of farmed rainbow trout $(S$. gairdneri R.). Thalassographica, 3: 21-34.

Papoutsoglou, S.E. and Voutsinos, G.A., 1988. Influence of feeding level on growth rate of Tilapia aureus (Steindachner) reared in a closed circulated system. Aquacul. Fish. Manage., 19: 291-298. https://doi. org/10.1111/j.1365-2109.1988.tb00432.x 
Ponzoni, R.W., Nguyen, H.N., Khaw, H.L., Hamzah, A. and Abu-Bakar, K.R., 2011. Genetic improvement of Nile tilapia (Oreochromis niloticus) with special reference to the work conducted by the World Fish Center with the GIFT strain. Rev. Aquacul., 3: 27-41. https://doi.org/10.1111/j.1753-5131.2010.01041.x

Rahim, A., Abbas, G., Gallus, L., Ferrando, S., Hafeezur-Rehman, M., Ghaffar, A. and Mateen, A., 2017a. Effect of ration level and feeding frequency on growth, nutrient utilization and body composition of juvenile black fin sea bream, Acanthopagrus berda (Forsskal 1775). Pakistan J. Zool., 49: $557-$ 563.

Rahim, A., Abbas, G., Naeem, M., Ferrando, S., Gallus, L., Hafeez-ur-Rehman, M., Ghaffar, A. and Mateen, A., 2017b. Effect of different oils on growth, feed conversion and body composition of juvenile black fin sea bream, Acanthopagrus berda (Forsskal 1775). Pakistan J. Zool., 49: 655-661. https://doi. org/10.17582/journal.pjz/2017.49.2.655.661

Saikia, S.K. and Das, D.N., 2015. Sustainable aquaculture: Agro-ecological role of and global overview. FAO, Rome, Italy. Periphyton in fish farming. Rev. Aquacul., 7: 172-186. https:// org/10.1111/raq.12062

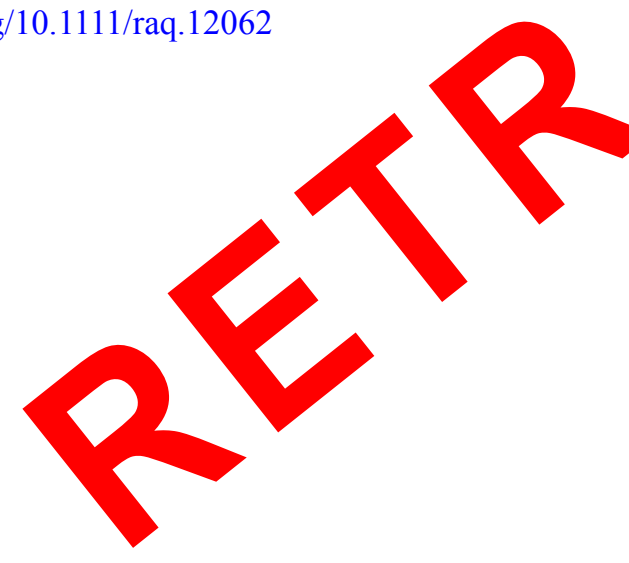

Shah, S.A., Malik, A., Kalhoro, H., Kalhoro, I.B., Wadhar G.M. and Maher, G.M., 2014. Growth performance of exotic catfish Pangas, Pangasius hypophthalmus (Sauvage, 1878) at Fish Hatchery Chilya Thatta, Sindh, Pakistan. Sindh Univ. Res. J. (Sci. Ser.), 46: 205-208.

Solomon S.G. and Okomoda, V.T., 2012. Growth performance of Oreochromis niloticus fed duckweed (Lemna minor) based diet in outdoor hapas. Int. J. Res. Fish. Aquacul., 2: 61-65.

Stickney, R.R., 1986. A review of tilapia salinity tolerance. Progn. Fish-Cultur., 48: 161-167. hitps://do1.org/10.1577/15488640(1986)48<161:TTOSW $>2$. 0. CO;2

Watanabe, W.O., Clark, J.H., Dunham, J.B., Wicklund, R.I. and Olla. BL. 1990. Culture of Florida red tilapia in marine cages: The effect of stocking density and dietary protein on growth. Aquaculture, 90: 123-134. https://doi.org/10.1016/00448486(90)90336-L

Yue, G.H., Lin,H.R. and Li, J.L., 2016. Tilapia is the fish for next generation aquaculture. Int. J. Mar. Ocean Technol., 3:11-13.

Zar, J.H., 1996. Bio-statistical analysis. Prentice-Hall Inc., New Jersey, pp. 662. 